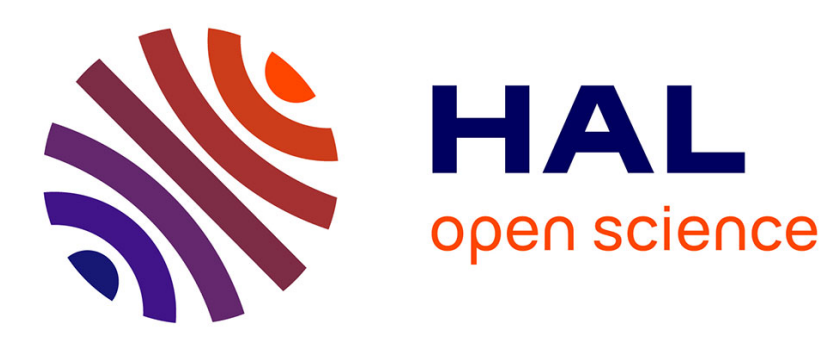

\title{
Modelling the transverse viscoelasticity of green wood using a combination of two parabolic elements
}

\author{
Sandrine Bardet, Joseph Gril
}

\section{To cite this version:}

Sandrine Bardet, Joseph Gril. Modelling the transverse viscoelasticity of green wood using a combination of two parabolic elements. Comptes Rendus Mécanique, 2002, pp.549-556. 10.1016/S16310721(02)01503-6 . hal-01180629

\section{HAL Id: hal-01180629 \\ https://hal.science/hal-01180629}

Submitted on 23 Nov 2015

HAL is a multi-disciplinary open access archive for the deposit and dissemination of scientific research documents, whether they are published or not. The documents may come from teaching and research institutions in France or abroad, or from public or private research centers.
L'archive ouverte pluridisciplinaire HAL, est destinée au dépôt et à la diffusion de documents scientifiques de niveau recherche, publiés ou non, émanant des établissements d'enseignement et de recherche français ou étrangers, des laboratoires publics ou privés. 


\title{
Modelling the transverse viscoelasticity of green wood using a combination of two parabolic elements
}

\author{
Sandrine Bardet, Joseph Gril \\ Laboratoire de mécanique et génie civil, Équipe Bois, Université Montpellier 2, CC081, place E. Bataillon, \\ 34095 Montpellier cedex 5, France
}

\begin{abstract}
The rigidity in radial compression at different levels of temperature and strain rate have been measured on green Boco, with a drastic softening around $60^{\circ} \mathrm{C}$ attributed to the glassy transition of lignin. The representation of experimental results in an approximated complex diagram revealed a secondary viscoelastic process occurring at lower temperature. A multiparabolic model was used for the analysis. For convenience, each parabolic element was replaced by a generalised Maxwell model with a modified-Gaussian relaxation spectrum. This model fitted correctly the observed behaviour of wood in the time range of 0.05 to $50 \mathrm{sec}$ and temperature between 10 to $90^{\circ} \mathrm{C}$.
\end{abstract}

rheology / wood / viscoelasticity / compression tests / temperature / modelling

\section{Modélisation de la viscoélasticité transverse du bois vert à l'aide d'une combinaison de deux éléments paraboliques}

Résumé

Le module de rigidité en compression radiale a été mesuré à différents niveaux de température et de vitesse de sollicitation sur des échantillons de Boco à l'état vert. La chute importante du module autour de $60^{\circ} \mathrm{C}$ est attribuée à la transition vitreuse des lignines. La représentation des résultats expérimentaux dans un plan complexe approché fait apparaître un deuxième mécanisme viscoélastique à basse température. Un modèle biparabolique permet d'interpréter les résultats. Chaque élément parabolique est remplacé par un modèle de Maxwell généralisé avec spectre quasi-gaussien des rigidités. Ce modèle représente correctement le comportement du bois observé expérimentalement pour une plage de temps comprise entre $0,05 \mathrm{~s}$ et $50 \mathrm{~s}$ et pour une température comprise entre 10 et $90^{\circ} \mathrm{C}$.

rhéologie / bois / viscoélasticité / essais de compression / température / modélisation

\section{Version française abrégée}

Le bois est un matériau polymérique dont le comportement mécanique dépend de la température, de l'humidité et du temps. Nous proposons ici de prendre en compte le paramètre temps dans l'étude du bois vert (bois venant d'être découpé) en vue de la modélisation viscoélastique des principaux

E-mail addresses: sandrine.bardet@umontpellier.fr (S. Bardet); joseph.gril@umontpellier.fr (J. Gril). 
phénomènes observés en mécanique de l'arbre (contrainte de croissance, déformation de maturation, recouvrance hygrothermique) et lors des premières étapes de la transformation du matériau (déroulage, sciage, thermoformage...).

Les travaux présentés ici sont basés sur une étude expérimentale et une proposition de modélisation rhéologique du comportement viscoélastique transverse du bois vert.

L'essence considérée est une essence guyanaise dense (infradensité égale à $1,09 \mathrm{~g} \cdot \mathrm{cm}^{-3}$ ) présentant une forte homogénéité du bois et une faible porosité. L'étude expérimentale concerne une série d'essais de compression radiale réalisée sur des échantillons saturés en humidité et débités à partir d'un arbre récemment abattu. Le dispositif expérimental et les échantillons sont immergés dans une cuve remplie d'eau dont la température est régulée entre 10 et $90^{\circ} \mathrm{C}$. La machine d'essai permet d'imposer une vitesse de déformation comprise entre $0,00011 \mathrm{~s}^{-1}$ et $0,11 \mathrm{~s}^{-1}$. On mesure à chaque température et chaque vitesse de déformation un module élastique radial apparent $\left(E_{R}\right)$. Les résultats expérimentaux $\left(E_{R}\right)$ sont représentés en fonction de la température à différentes vitesses de déformation (Fig. 1). La chute des propriétés mécaniques autour de $60^{\circ} \mathrm{C}$ est caractéristique de la transition vitreuse des lignines. Les résultats peuvent être représentés d'une autre manière en utilisant une méthode proposée par Huet, basée sur les relations d'Alfrey, qui permet de construire un plan complexe approchée (PCA) à partir des données d'essais quasistatiques. Les résultats des essais de compression placés dans le PCA font apparaitre deux mécanismes viscoélastiques (Fig. 2), le mécanisme 1 est entièrement visible dans la plage de temps correspondant aux essais de compression, il se déroule entre 30 et $90^{\circ} \mathrm{C}$, une partie d'un deuxième mécanisme apparait dans le PCA pour des températures inférieures à $30^{\circ} \mathrm{C}$.

La représentation dans le PCA conduit au choix d'un modèle multiparabolique (Fig. 3), ce type de modèle a été proposé par Huet pour représenter le comportement viscoélastique du bois sec. L'association d'éléments paraboliques est plus difficile à traiter numériquement que l'association d'éléments de type Maxwell. On montre qu'un élément parabolique est quasiment équivalent à une série d'éléments de type Maxwell généralisé avec spectre quasi-gaussien des rigidités (Fig. 4). Le modèle spectral est caractérisé, entre autres, par la demi-largeur du spectre $(d)$ et un paramètre de forme $(g)$. Son équivalence avec le modèle parabolique caractérisé par le paramètre $p$ (Fig. 5) conduit à une relation entre $d, g$ et $p$ (Fig. 6). Le modèle composé de deux spectres est calé sur les données expérimentales (Tableau 1) et les résultats expérimentaux et modélisés sont comparés dans le graphe module-température et dans le PCA (Figs. 1 et 2). L'interprétation des données à l'aide du modèle permet d'expliquer l'effet relatif des deux mécanismes à différentes températures (Fig. 7).

\section{Introduction}

Wood is a polymeric material which exhibits a viscoelastic behaviour influenced by temperature and humidity. A reduction of bound-water content provokes complex phenomena, made evident by an anisotropic shrinkage and rigidification, but also by a transient increase of molecular mobility known as the mechanosorptive effect [1]. This study, however, is restricted to the case of water-saturated wood, particularly 'green' or never-dried wood which can be expected to behave like any semi-crystalline polymer and exhibit usual features of time-dependent and thermoactivated behaviour. Although the behaviour of green wood is not so well documented as that of the dry material in service conditions, more knowledge would be useful for improving the early stages of the transformation process. The green state is that of wood during tree life: a correct modelling of residual stresses in tree stems should take into account the viscosity [2]. The progressive log-end splitting, accelerated by boiling, is a practical consequence of the existence of locked-in strains originating in the mechanical conditions of the cell-wall maturation [3]. Transformation processes such as veneer cutting, sawing or some of wood forming have to be performed in the green state, and progress in their numerical modelling relies on a better knowledge of green wood rheology, especially transversally to the fibre direction [4]. 
In the 1980s, significant progress on wood rheology has been gained by French teams, in particular Huet and coworkers from CTBA (the French Technical Center for Wood and Furniture) have demonstrated the applicability to wood of multiparabolic models commonly used for other materials such as asphalt. Their method relied on a representation of the complex modulus, or, in the case of quasi-static tests, an approximation of the complex modulus [5]. It was at that time mainly applied to air-dry wood loaded along the fibre. In the present paper, we will propose another application of that method, in the case of a dense hardwood loaded transversally in the green state. We will also propose an alternative to parabolic models, based on a generalised Maxwell model allowing a spectral decomposition of the relaxation function.

\section{Materials and methods}

A guyanese species, Bocoa prouacensis Aubl. (Boco) was chosen for this study. As a tropical wood, it presents the advantage of low within-tree variability and good homogeneity. Its very high basic density $\left(1.09 \pm 0.012 \mathrm{~g} \cdot \mathrm{cm}^{-3}\right.$ in our sample) and consequently low porosity implies that the macroscopic behaviour transversally to the fibres is close to the bulk behaviour of the cell-wall material, with almost no contribution from cell-wall bending. Bars of section $30 \mathrm{~mm}$ in $R$ direction by $30 \mathrm{~mm}$ in $T$ direction were cut from green wood logs and divided into series of well-matched cubes of width $30 \mathrm{~mm} 5$ days after tree felling, then kept soaked in water 1 to 8 days before testing.

Compression tests were performed on a MTS testing machine fitted with a $100 \mathrm{kN}$ load cell. Specimen and testing system were placed in a water bath controlled at constant temperature to within $0.1{ }^{\circ} \mathrm{C}$ using electrical heating. To avoid a thermal drift of the load cell, an insulation system was installed. To reach temperatures below $30^{\circ} \mathrm{C}$, a cooling system was added. Just before being subjected to the compression the specimens were heated in water about $10-15 \mathrm{mn}$ at the bath temperature to ensure that they had fully reached thermal equilibrium. Tests were performed over a temperature range of 10 to $90^{\circ} \mathrm{C}$ at intervals of $10^{\circ} \mathrm{C}$.

Since only the distance between the fixed and moving platens was known, the elastic deformation of the frame had to be measured separately to evaluate, by difference, the relative displacement of the upper and lower face of the specimen, taken as specimen 'strain'. The 'stress' was calculated as the applied load divided by the initial cross-section measured at room temperature. The total displacement was increased linearly at various speed, corresponding for the specimen to a strain rate ranging between 0.00011 and $0.11 \cdot \mathrm{s}^{-1}$. For each strain rate and temperature, an apparent radial elastic modulus $\left(E_{R}\right)$ was obtained as the initial slope of the corresponding strain-stress curve, without consideration of heterogeneous strain distribution caused by friction of the specimen on the platens.

\section{Experimental results}

The evolution of $E_{R}$ in function of temperature (Fig. 1) is typical of a viscoelastic material, the drastic decrease of $E_{R}$ around $60^{\circ} \mathrm{C}$ could be brought about by the glassy transition of lignin, one of the polymeric constituents of wood [6-8]. The influence of strain rate is, as expected, strongest within the glassy transition; it remains, however, rather important in the lower temperature range, suggesting the occurrence of a secondary transition.

A representation relying on the use of the complex plane, proposed by Huet $[5,9,10]$, will be used to analyse our data. This method allows us to represent data from static tests in the same way as vibratory tests. Dynamical data can be plotted in a Cole-Cole graph or complex plane using complex modulus ( $E^{\prime \prime}$ with respect to $E^{\prime}$ ) or compliance $\left(J^{\prime \prime}\right.$ with respect to $J^{\prime}$ ). In the case of a relaxation test, a similar plot can be built from the relaxation function $R(t)$ using Alfrey's method [11,12], approximating the complex modulus as:

$$
E^{\prime} \approx R(t) \quad \text { and } \quad E^{\prime \prime} \approx-\pi / 2 \frac{\mathrm{d} R}{\mathrm{~d} \ln t}
$$




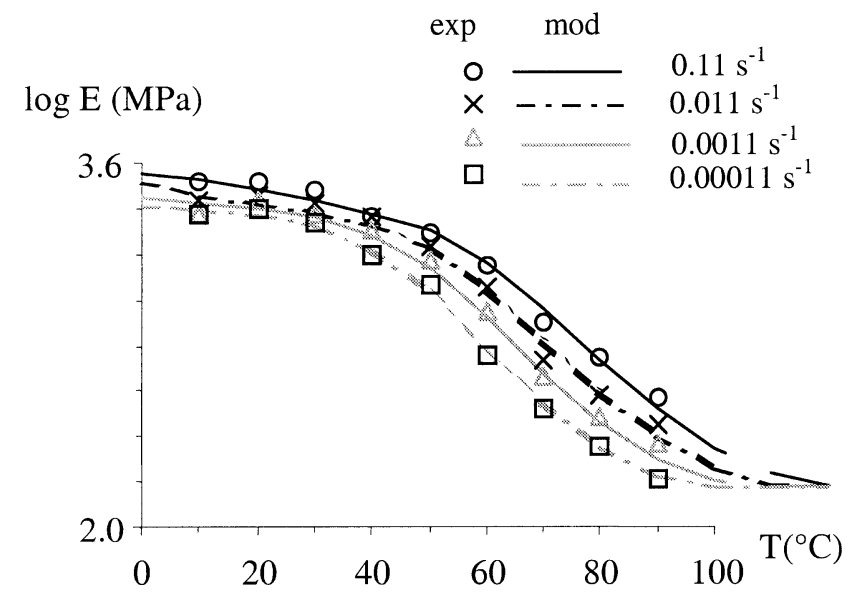

Figure 1. Evolution of the logarithm of $E_{R}$ as function of temperature at different strain rates. Symbols refer to experimental data and lines to the fitted model (see Section 4.2).

Figure 1. Évolution du logarithme de $E_{R}$ en fonction de la température à différentes vitesses de déformation. Les points représentent les résultats expérimentaux et les lignes font référence au modèle (voir Section 4.2).
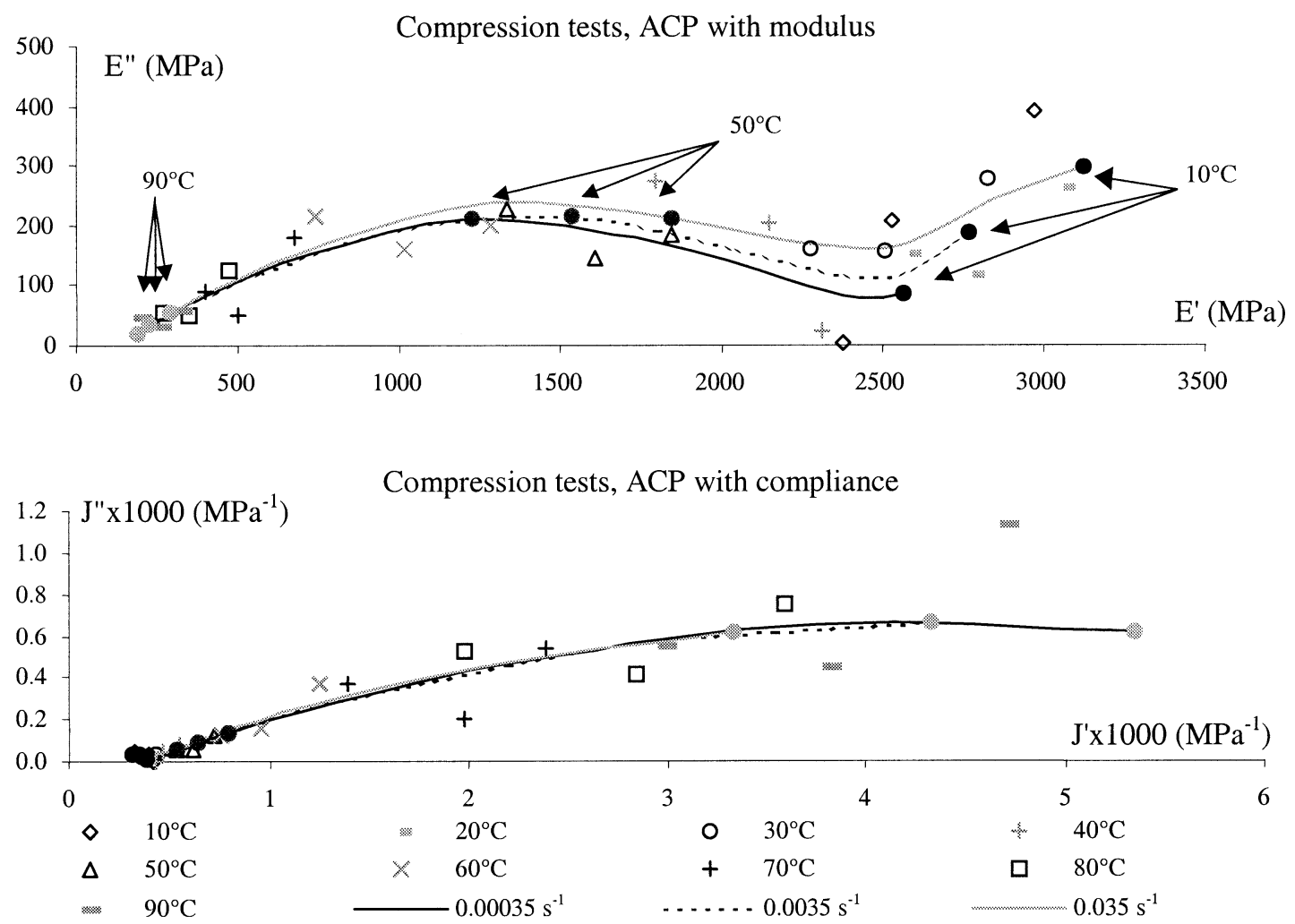

Figure 2. ACP from compression tests: (a) rigidity; (b) compliance. Symbols refer to experimental data and lines to the fitted model (see Section 4.2). Calculated values for 10,50 and $90^{\circ} \mathrm{C}$ are shown by arrows.

Figure 2. PCA des essais de compression: (a) rigidité ; (b) complaisance. Les points représentent les résultats expérimentaux et les lignes font référence au modèle (voir Section 4.2). Les valeurs théoriques pour 10,50 et $90^{\circ} \mathrm{C}$ sont pointées par des flèches.

In the present case, the apparent radial elastic modulus $\left(E_{R}\right)$ is known at different levels of temperature $(T)$ and strain rate $(v=\mathrm{d} \varepsilon / \mathrm{d} t)$ so the latter relations are discretised. Since the range of deformation $(\Delta \varepsilon)$ corresponding to the evaluation of $E_{R}$ was little dependent on $T$ and $v$, differences of loading 
speed $(\Delta \varepsilon / \Delta t)$ are equivalent to differences of measuring time $(t \approx \Delta t)$, so that $\Delta \ln t=\ln \left(t_{i+1} / t_{i}\right) \approx$ $\ln \left(v_{i} / v_{i+1}\right)$.

This enables us to apply the principle of Alfrey's method, approximating the complex modulus as:

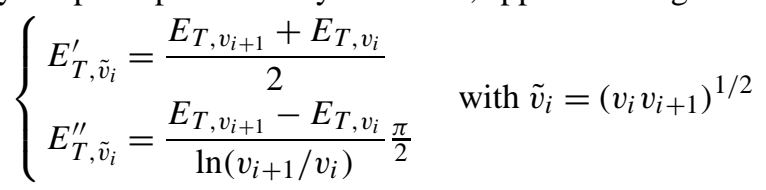

The resulting approximated complex plane (ACP) is plotted in Fig. 2 for Boco, showing both the complex modulus and complex compliance. The latter has been calculated as:

$$
J^{\prime}=\frac{E^{\prime}}{E^{\prime 2}+E^{\prime \prime 2}} \quad \text { and } \quad J^{\prime \prime}=\frac{E^{\prime \prime}}{E^{\prime 2}+E^{\prime \prime 2}}
$$

Fig. 2(a) suggests the occurrence of two viscoelastic processes. At the time scale corresponding to compression test (between some hundredths and ten seconds), a first process is completely visible between 30 and $90^{\circ} \mathrm{C}$ (process numbered 1) while a part of a second one is revealed by the ACP for lower temperature (process numbered 2).

\section{Modelling}

\subsection{Theoretical presentation of the model}

To analyse more deeply the viscoelastic behaviour and obtain a valuable description of the thermal activation, we applied a modelling approach on mechanical tests results. The stress-strain relationship which governs linear viscoelastic behaviour can be obtained using an appropriate rheological model. Huet proposed the use of a combination of spring and parabolic elements. A multi-parabolic model was shown to be relevant for the modelling of wood behaviour over a large experimental window [5]. As compression data in the ACP revealed two processes, a bi-parabolic model (a single spring in parallel with two parabolic elements) will be chosen. The model is presented in Fig. 3: each link is characterised by the spring rigidity $E_{k}$, a characteristic time $\tau_{k}$ and a parabolic parameter $p_{k}\left(0<p_{k}<1\right)$. The representation of this type of model in the complex plane is two portions of circle. The intermediate zone corresponding to the simultaneous occurrence of the two processes would reduce to a point on the $x$-axis for $\tau_{2} \gg \tau_{1}$, whereas for $\tau_{2} / \tau_{1} \rightarrow 1$, they would merge into an apparently unique process.

Parabolic elements are more difficult to handle than conventional rheological models made of combinations of springs and dashpots where a stiffness is assigned to the spring and a relaxation time (or a viscosity) to the dashpot. It can be demonstrated that a generalised Maxwell model with a finite numbers of simple Maxwell elements is practically equivalent to a parabolic element provided a relevant set of

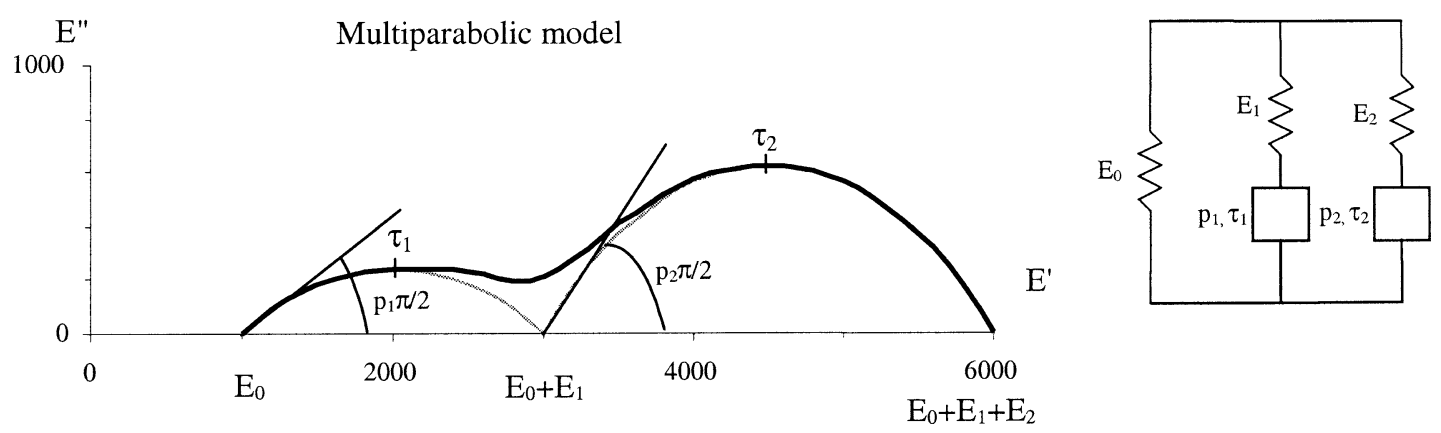

Figure 3. Multiparabolic model.

Figure 3. Le modèle multiparabolique. 
parameters has been chosen. We propose the use of models such as those of Fig. 4, where the rigidities $\left(E_{k}\right)$ follow a modified Gaussian distribution respective to the logarithm of time relaxation $\left(\tau_{k}\right)$. The parameter $\delta$ is taken equal to 1 , and $N$ is calculated in order to truncate the distribution as soon as rigidities are lower than $5 \%$ of the maximum central value. A parabolic element characterised by $E, \tau$ and $p$ and represented by a portion of circle in the complex plane is practically equivalent to a generalised Maxwell distribution characterised by $E, \tau, d$ and $g$, where $d$ and $g$ are related to $p$ as shown in Fig. 6 .

The equivalence between the complex plane (CP) and its approximation (ACP) is more relevant for smaller $p$ values, meaning a broader spectrum. Fig. 5 compares, for two values of $p$, the representation in the $\mathrm{CP}$ and the ACP of a parabolic element, as described by its equivalent Maxwell distribution.

The influence of temperature is taken into account through an Arrhenius law which expresses timetemperature equivalence. The shape of the relaxation spectrum is assumed constant; only the central value of time relaxation for each mechanism number $i(i=1$ or 2$)$ depends on temperature as follows:

$$
\tau_{i}=\tau_{i, r} \mathrm{e}^{\left(W_{i} / R\right)\left(1 / T-1 / T_{r}\right)}
$$

where $i$ refers to mechanism 1 or $2, \tau_{i}$ (sec) is the central value of relaxation time, $W_{i}$ is the activation energy, $R$ is the constant of perfect gas $\left(R=0.0031 \mathrm{~kJ} \cdot \mathrm{mol}^{-1}\right), T\left({ }^{\circ} \mathrm{K}\right)$ is the temperature, $T_{r}$ is the reference temperature $\left(T_{r}=50^{\circ} \mathrm{C}=323 \mathrm{~K}\right.$ for both mechanisms), $\tau_{i, r}$ is the value of $\tau_{i}$ when $T=T_{r}$.
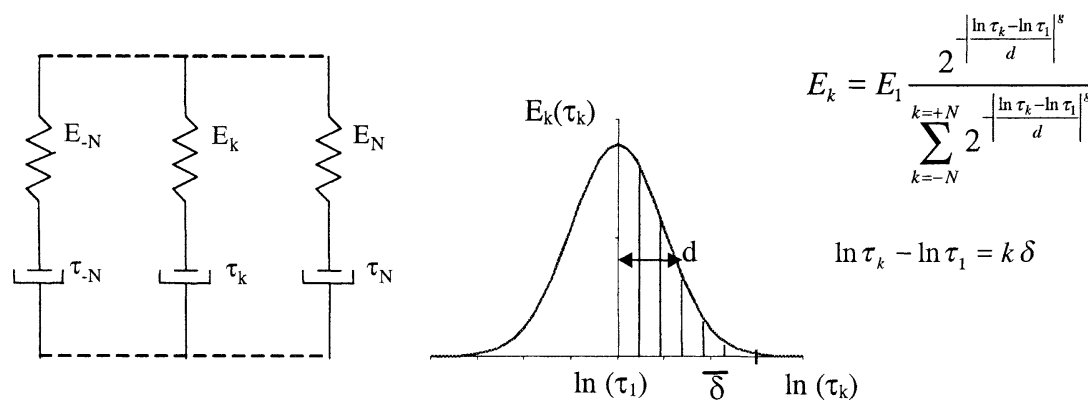

Figure 4. Generalised Maxwell model with quasi-Gaussian spectrum. $d$ is the half-width measured at the half-height of the spectrum, $\delta$ is the discretisation parameter, $\tau_{1}$ is the central value of relaxation times, $E_{1}$ is the sum of $E_{k}$.

Figure 4. Le modèle de Maxwell généralisé avec spectre quasi-gaussien.
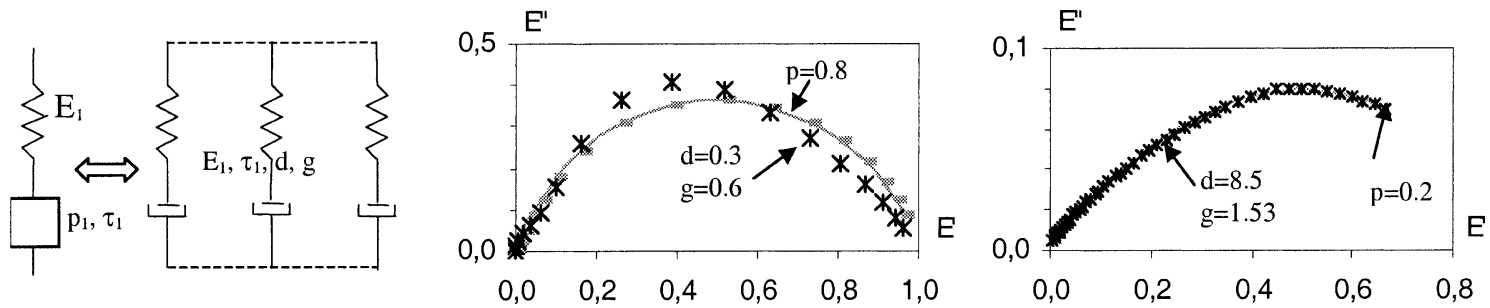

Figure 5. Equivalence between parabolic element and spectral decomposition by a generalised Maxwell model, and comparison between CP and ACP. The grey line correspond to the parabolic, grey dash points to its approximation by a generalised Maxwell, black crosses to the approximated complex rigidity calculated using equation (1) for the generalised Maxwell, $E_{1}=1$ and $\tau_{1}=1$.

Figure 5. Équivalence entre l'élément parabolique et la décomposition spectrale par un modèle de Maxwell généralisé, et comparaison entre le plan complexe et le PCA. La ligne grise correspond au modèle parabolique, les tirets gris à son approximation par un Maxwell généralisé, les croix noires à la rigidité complexe du Maxwell généralisé approximée par l'équation (1), $E_{1}=1$ et $\tau_{1}=1$. 
Figure 6. Relation between the parabolic parameter $p$ and the parameters $d$ and $g$ of the equivalent Maxwell distribution.

Figure 6. Relation entre le paramètre parabolique $p$ et les paramètres $d$ et $g$ de la distribution de Maxwell équivalente.

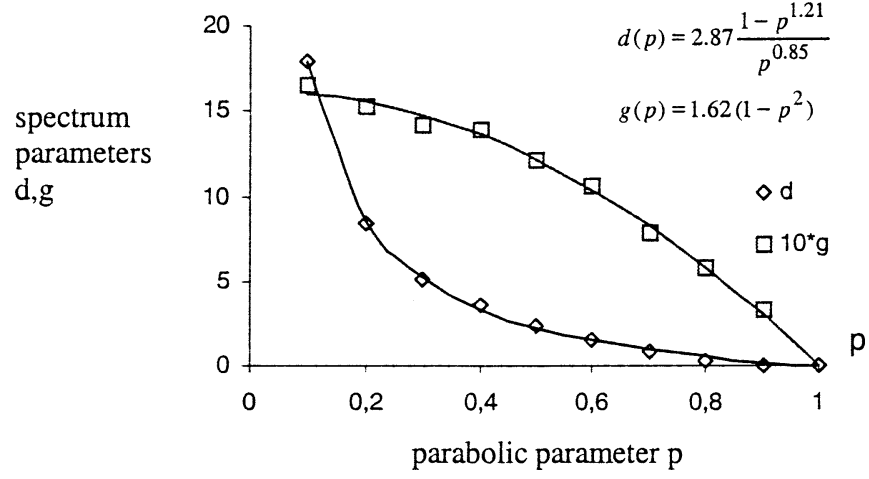

Table 1. Parameters of the model

Tableau 1. Paramètres du modèle

\begin{tabular}{llllc}
\hline Parameters & & & & \\
\hline Elastic rigidity & $E_{0}(\mathrm{GPa})$ & 0.15 & & Mechanism 2 \\
\cline { 2 - 3 } & Mechanism 1 & & $E_{2}(\mathrm{GPa})$ & 1.34 \\
\cline { 2 - 5 } Delayed rigidity & $E_{1}(\mathrm{GPa})$ & 2.30 & $d_{2}$ & 1.25 \\
Spectrum width & $d_{1}$ & 7.25 & $g_{2}$ & 10.78 \\
Spectrum shape & $g_{1}$ & 1.51 & $p_{2}$ & 0.72 \\
Parabolic parameter & $p_{1}$ & 0.26 & $\delta_{2}$ & 0.5 \\
Spacing in log $(\tau)$ scale & $\delta_{1}$ & 1 & $N_{2}$ & 10 \\
Half-number of Maxwell elements & $N_{1}$ & 13 & $\tau_{2, r}(\mathrm{~s})$ & 0.00051 \\
Medium characteristic time & $\tau_{1, r}(\mathrm{~s})$ & 13.7 & $W_{2}\left(\mathrm{~kJ} \cdot \mathrm{mol}^{-1}\right)$ & 117 \\
Activation energy & $W_{1}\left(\mathrm{~kJ} \cdot \mathrm{mol}^{-1}\right)$ & 384 & & \\
\hline
\end{tabular}

\subsection{Application to the experimental results}

The modelled expression of the apparent radial stiffness $E_{R}$ is:

$$
E\left(t_{0}\right)=E_{0}+\sum_{-N_{1}}^{N_{1}} E_{1 k} \mathrm{e}^{-t_{0} / \tau_{1 k}}+\sum_{-N_{2}}^{N_{2}} E_{2 k} \mathrm{e}^{-t_{0} / \tau_{2 k}}
$$

where $E_{i k}$ follows a modified Gauss distribution expressed in Fig. 4, and $t_{0}$ is the half-duration of the loading up to a given strain level of about $1 \%$. This $t_{0}$ is also the time used for the evaluation of the slope in the stress-strain curves; it depends on the strain rate of the compression test, and equals to $0.045,0.45$, 4.5 et $45 \mathrm{~s}$ for strain rates of $0.11,0.011,0.0011$ and $0.00011 \cdot \mathrm{s}^{-1}$, respectively. The model can fit the experimental data provided that a relevant set of parameters is chosen. The 9 parameters of the model ( $E_{0}, E_{i}, W_{i}, \tau_{i, r}, p_{i}$ for $i=1$ and 2 ) have been determined in order to minimise the sum of square relative differences between model and experimental data from compression tests at different temperature and strain rate, $\Sigma\left(E_{\text {model }} / E_{\text {exp }}-1\right)^{2}$. They are listed in Table 1 . The modelled curves have been plotted together with experimental points in Fig. 1, and Fig. 2 shows the comparison in the rigidity and compliance ACP.

The model involves two mechanisms which are separated at low temperature in the time scale corresponding to compression tests. Fig. 7 illustrates the evolution of both rigidities spectra at three values of temperature $\left(10,50\right.$ and $\left.90^{\circ} \mathrm{C}\right)$. The experimental window is represented relatively to the time scale. 

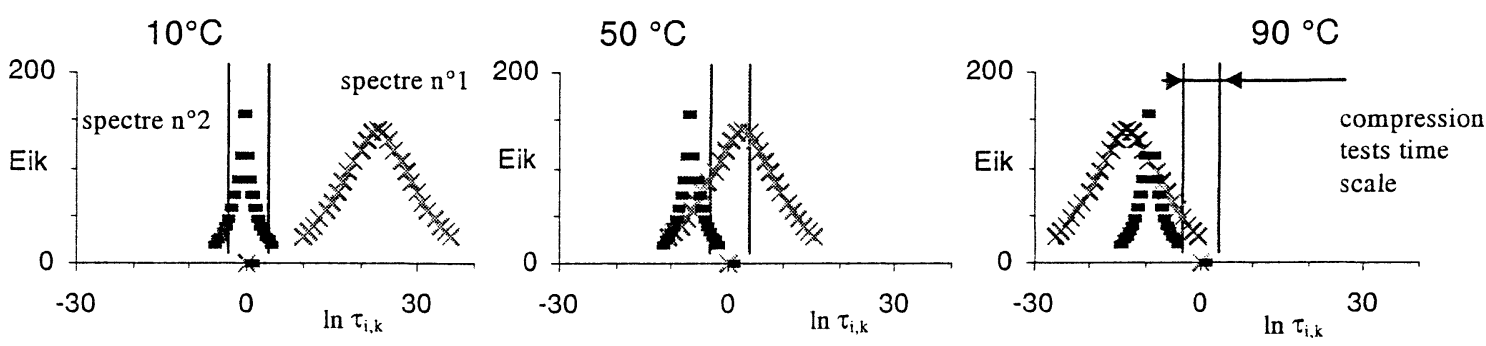

Figure 7. Relative position of spectra 1 and 2 in function of temperature.

Figure 7. Position relative des spectres 1 et 2 en fonction de la température.

Mechanism $n^{\circ} 2$ is narrow and slightly influenced by temperature whereas mechanism $n^{\circ} 1$ is spread and markedly influenced by temperature. At $10^{\circ} \mathrm{C}$, experimental window is centred only on the mechanism $\mathrm{n}^{\circ} 2$. At $50^{\circ} \mathrm{C}$, the experimental window is centred on the mechanism $\mathrm{n}^{\circ} 1$, the softening phenomenon is maximum; this corresponds to the inflection point around $60^{\circ} \mathrm{C}$ in the modulus versus temperature curve. At $90^{\circ} \mathrm{C}$, only the tail of spectrum $\mathrm{n}^{\circ} 1$ is observed.

\section{Conclusion}

The multiparabolic model could be used successfully to describe the transverse viscoelastic behaviour of a dense wood like Boco in the green state, in the time range of 0.05 to $50 \mathrm{~s}$ and temperature between 20 and $90^{\circ} \mathrm{C}$. The use of the approximated complex plane has been tried, both for suggesting the appropriate model and for evaluating the model parameters prior to any fitting procedure. Further experimental work is required to extend the time range observed and check the validity of the model.

\section{References}

[1] J. Gril, Principles of mechano-sorption, in: S. Aicher (Ed.), International Conference on Wood Mechanics, Stuttgart, Germany, 14-16 May 1996, FMPA-Otto-Graf-Institut, 1996, pp. 1-16.

[2] J. Gril, M. Fournier, Contraintes d'élaboration du bois dans l'arbre : un modèle multicouche viscoélastique, in: 11ème Congrès Français de Mécanique, Lille-Villeneuve d'Ascq, 6-10 September 1993, pp. 165-168.

[3] J. Gril, B. Thibaut, Tree mechanics and wood mechanics: relating hygrothermal recovery of green wood to the maturation process, Ann. Sci. Forestières 51 (1994) 329-338.

[4] B. Thibaut, J. Gril, M. Fournier, Mechanics of wood and trees: some new highlights for an old story, C. R. Acad. Sci. Paris, Série IIb 329 (2001) 701-716.

[5] C. Huet, P. Navi, Multiparabolic multitransition model for thermo-viscoelastic behaviour of wood, in: The Winter Annual Meeting of the ASME, Dallas, Texas, 25-30 November 1990, pp. 17-24.

[6] E.L. Back, L. Salmen, Glass transitions of wood components hold implications for molding and pulping processes, Tappi J. 7 (1982) 107-110.

[7] D.A.I. Goring, Thermal softening of lignin, hemicellulose and cellulose, Pulp and Paper Magazine of Canada 64 (1963) T517-T527.

[8] L. Salmen, Viscoelastic properties of in situ lignin under water-saturated conditions, J. Material Sci. 19 (1984) 3090-3096.

[9] C. Huet, Some aspects of the thermo-hygro-viscoelastic behaviour of wood, in: P. Morlierr (Ed.), Mechanical Behaviour of Wood, Bordeaux, 8-9 June 1988, pp. 104-118.

[10] C. Huet, Représentation des modules et complaisances complexes dans les plans complexes arithmétique et logarithmique, Cahiers du groupe français de rhéologie 1 (5) (1967) 237-258.

[11] T. Alfrey, Mechanical Behaviour of High Polymers, Interscience, New York, 1948, p. 581.

[12] A.S. Nowick, B.S. Berry, Anelastic Relaxation in Crystalline Solids, Academic Press, 1972, p. 677. 